\title{
NEW DISTRIBUTIONAL DATA ON THE ORTHOPTERA (SALTATORIA) OF THE NORTHERN DODECANESE (“SOUTHERN SPORADHES”) ARCHIPELAGO, GREECE
}

\author{
K. P. Papapavlou*
}

\begin{abstract}
A catalogue of Orthoptera species collected during 1997 from isolated islets of the northern Dodecanese archipelago, Greece, is presented. Information on related taxonomical aspects and ecological parameters is also given.

Keywords: Orthoptera, Gryllidae, Gryllotalpidae, Acrididae, Tettigoniidae, Dodecanese, Greece, archipelago, island.
\end{abstract}

\section{RESUMEN}

Nuevos datos sobre los Ortópteros (Orthoptera, Saltatoria) del archipiélago del norte del Dodecaneso (Espóradas del sur, Grecia)

Se presenta un catálogo de especies de Ortópteros recogidos durante 1997 en pequeñas islas aisladas del archipiélago del norte del Dodecaneso (Espóradas del sur, Grecia) También se incluye información sobre algunos aspectos taxonómicos y ecológicos de las especies recolectadas.

Palabras clave: Orthoptera, Gryllidae, Gryllotalpidae, Acrididae, Tettigoniidae, Dodecaneso, Grecia, archipiélago, isla.

\section{Introduction}

Orthoptera are one of the most thoroughly studied invertebrate taxa within mainland and insular Greece: approximately 150 titles, covering every major geographical division of the country, are reported to have been published up to 1984 (Willemse, 1984), with a few new papers emerging since then. A small -yet important regarding its wealth of information- number of these works refers to the larger islands of the Dodecanese ("Dhodekanisos" or Southern Sporadhes) archipe- lago at the southeastern corner of the Aegean Sea, where foreign scientists undertook extensive sampling at best during the first half of the $20^{\text {th }}$ century (short review in Jannone, 1940). Since the 50s, published information tends to fit into a larger geographical context or refers only to certain Orthopteroid taxa (as in Willemse, 1982; Baccetti, 1992; etc.).

This paper aims to present information on the Orthoptera species collected from some of the smallest and least accessible islands of the northern part of the Dodecanese archipelago from which to my

* University of Athens, Department of Biology, Athens, Greece Present address: Artemidos 15, Metamorfosi, Attiki, GR - 144 52, Greece. e-mail: kpapapavlou@ath.forthnet.gr \& EPEM S.A., Aharnon 141b \& Laertiou, GR - 104 46, Athens, Greece. 
knowledge, there are no other published records up to this moment (Fig. 1). For several of these taxa the taxonomic status remains dubious and the corresponding biogeographic knowledge is only based on scarce data. It is therefore hoped that the collected material, apart from providing new faunistic records, may also help in elucidating ambiguous past information on systematics, biogeography and perhaps ecology of certain taxa in the region.

\section{Materials and methods}

Sampling took place from the middle of May 1997 to the beginning of July 1997. The area sampled includes 13 different islands and islets within the Northern Dodecanese archipelago - Greece, at the southeastern Aegean sea (Appendix, Fig. 1). Sampling intensity and duration varied in a non-systematic way between different islands, in several cases determined by the prevailing weather conditions. Sampling took place either randomly (by sweeping during daylight) or passively (by pitfall traps); a few samples were handed by local people or other scientists participating in the expedition. A few Tettigonnidae, Gryllidae, Rhaphidophoridae, Oedi-podinae and Gomphocerinae specimens remain unidentified and are not presented here.

Pitfall trapping is a method widely used to sam ple soil beetles such as Carabidae and Tenebrionidae and other soil invertebrate taxa (e.g. Ausden, 1996) and it was originally employed for this purpose (data on soil beetles are to be presented elsewhere); however, when targeting beetles, the same method unintentionally gave rise to an important number of individuals and species of Orthoptera which, due to their nocturnal or cryptic behaviour, would have been unlikely to be caught by means of regular sweeping (e.g. Gryllidae, Gryllotalpidae). The pitfall traps used in the Northern Dodecanese field work consisted of a plastic water cup half filled with ethylene-glycol (acting as a preservative of high evaporation point) placed in a hole dug in the soil so that the upper part of the cup stays exactly at the upper soil level. One placed in the field, pitfall traps operate continuously until emptied so specimens caught in there can not be exactly dated. The Appendix provides information on sites within the study area where pitfall traps have been used.

The vegetation in the archipelagos has been described in Economidou (1995) and Economidou et al. (1999). As several of these islands are part of the Natura 2000 network, the main habitat types were recently reassessed in detail according to the EU Habitats Directive 92/43/EE (Romão, 1996). Descriptions for the particular sampling sites (all close to or at sea level) are given in Appendix.

\section{Results}

Ensifera - Tettigonioidea

Tettigoniidae - Phaneropterinae

Poecilimon sanctipauli Brunner von Wattenwyl, 1878

Lipsos, Hora, 19 May 1997, 1 ㅇ at phrygana.

Leros, Gouves 20 May 1997, $10^{7}$, by roadside close to the wetland and the airport.

REMARKS: The species is known from the southeastern Aegean (the Greek islands of Samos, Kos, Rhodos and Kalimnos) and soutwestern Turkey; these findings from Lipsos and Leros, being new reports, fall within the known biogeographical range. Among the thirteen (or twelve) Poecilimon taxa the Aegean is currently known to hold, $P$. sanc tipauli is one of the few reported to occur both in the Aegean and the Asian mainland coast (Willemse, 1982, 1984a; Heller \& Reinhold, 1992; Willemse \& Heller, 1992). Poecilimon sanctipauli has been recorded from a variety of tree and shrub vegetation types in Greece and Turkey with an altitudinal range varying from sea level to locations > $1500 \mathrm{~m}$ a.s.l. (Willemse, 1982; Önder et al., 1999c; Ünal, 2000; etc.); the records from Lipsos and Leros can not be seen as linking the species presence to a certain habitat type.

It is speculated that the present-day distribution of the genus is a result of dispersal (and isolation) in the early tertiary Egeis by means of the Miocene small plates which then provided connections with European Asia (La Greca, 1999).

$$
\text { Tettigoniidae - Decticinae }
$$

Decticus albifrons (Fabricius, 1775)

Lipsos, Hora, 23 June 1997, $10^{\pi}$.

REMARKS: This taxon is widely present in Greece and the Mediterranean, its range extends to southwest Asia.

Eupholidoptera smyrnensis (Brunner von Wattenwyl, 1878)

Lipsos, Hora, 23 June 1997, 1 ㅇ at phrygana / Lipsos, Hora, July 1997, $1 \sigma^{7}$ at phrygana.

REMARKS: The species is known from a few sites in northern and insular Greece (western 


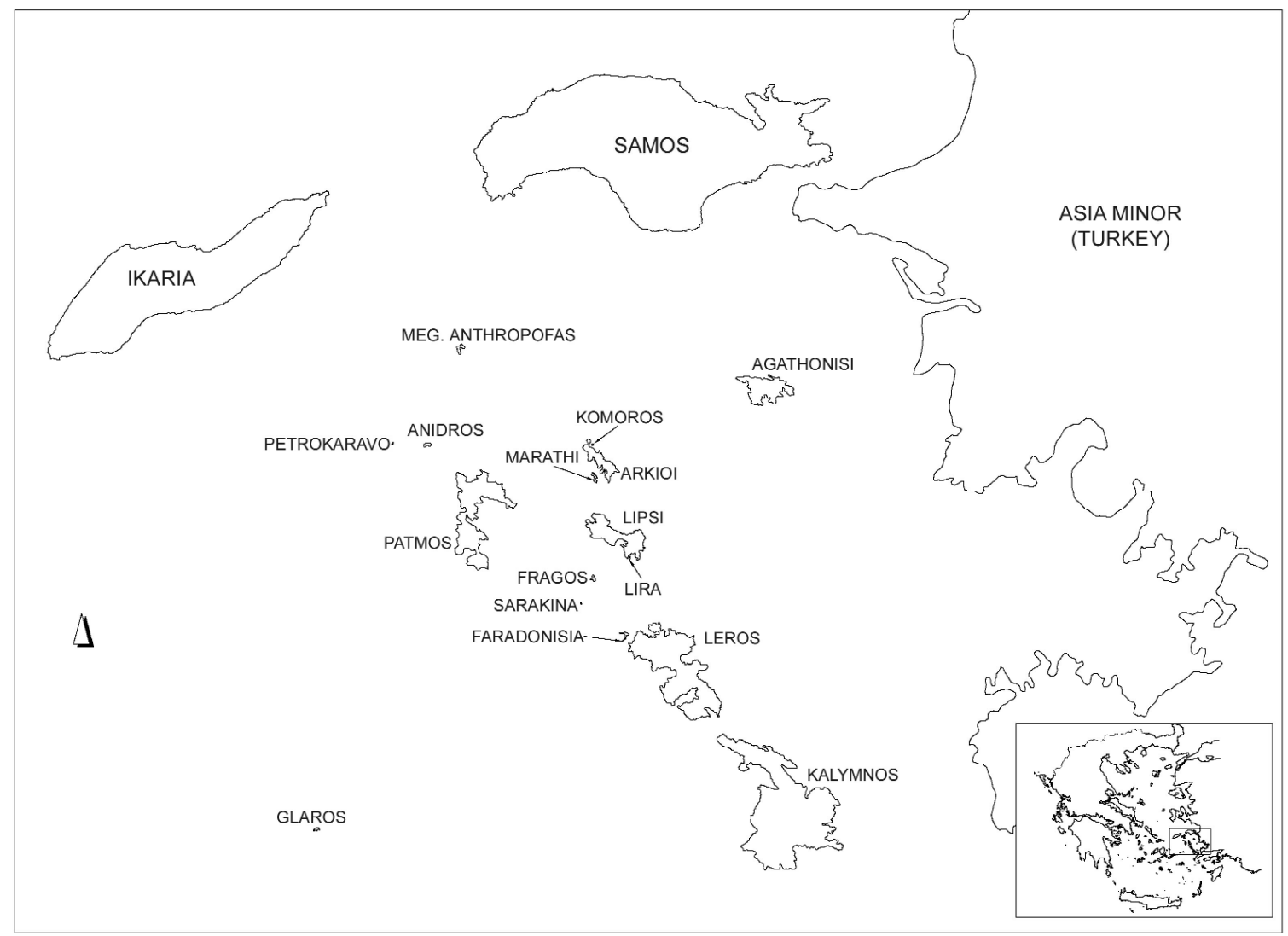

Fig. 1.- Map of the northern Dodecanese archipelago, Greece. Only major islands and islets mentioned in the text are shown. Scale is approximate.

Fig. 1.- Mapa del archipiélago del norte del Dodecaneso (Espóradas del sur), Grecia. Solo se muestran las islas grandes o las mencionadas en el texto. La escala figurada es aproximada.

Macedonia, Thraki and a few Aegean islands) and western Turkey); it is the only member of the genus currently known from the southern Sporadhes area (Willemse, 1980; Salman, 1983). As no key for the females of Greek species is known to the author, the specimens from Lipsos were identified according the shape of their subgenital plate which was similar to the one depicted in Salman (1983).

Bucephaloptera bucephala (Brunner von Wattenwyl, 1878)

Lipsos, Hora , July 1997, $10^{\pi}$.

REMARKS: This species has been reported from the northern Balkan peninsula (Romania) to Turkey including several localities in mainland and insular Greece: in the Dodecanese, previous records had been limited to the islands of Kos and Rodos (Willemse, 1984). Karabag (1951) refers to it as «a variable species» and by far supports distinction at specific level on male characteristics. Indeed, although the key for the Greek Bucephaloptera describes the upper part of the face as black-colored (Willemse, 1985), the specimen from Lipsos preserves a light brown tint throughout the head.

$$
\text { Grylloidea }
$$

Gryllidae - Gryllinae

\section{Gryllus bimaculatus De Geer, 1773}

Lipsos, 26 May-28 June 1997 (wetland pitfall traps), 10 $0^{\top}, 3 ㅇ ㅜ ㅇ$. 
REMARKS: This species is present in much of southern Europe, Asia and Africa.

Melanogryllus desertus (Pallas, 1771)

Leros, Gouves, 20 May-21 June 1997 (pitfall traps), 10 $\sigma^{7} \sigma^{7}$; 9 우 우. Pitfall traps had been placed within the Gouves coastal marsh.

REMARKS: To the knowledge of the author, this is the first published report of the species from the Southern Sporadhes area; it has also been recorded from several areas in the Greek mainland, the islands of Samos and Samothraki in the Aegean and the Ionian islands (Willemse, 1984). The taxon is widely distributed in southern Europe and northern Africa to central Asia and different forms are described according to the length of the tegmina, ie brachypterous or macropterous (Llorente del Moral, 1980; Gorochov \& Llorente, 2001). The specimens from Leros are all brachypterous.

Eumodicogryllus $\boldsymbol{c f}$. bordigalensis (Latreille, 1804)

Leros, Gouves, 21 June 1997, $50^{7} 0^{7} ; 7$ 우 우.

Leros, Gouves, 20 May-21 June 1997 (pitfall traps), $3 \sigma^{\top} \sigma^{\top}$; 43 우 ㅇ. Pitfall traps had been placed within the Gouves coastal marsh.

Lipsos, 26 May-28 June 1997 (wetland pitfall traps), 20 $\sigma^{7}$, 8 우 우. Pitfall traps had been placed within the small wetland close to the island port.

REMARKS: Specimens were identified according to the form of the male genitalia as presented in Willemse (1985) (drawings from Chopard, 1962), there attributed to Tartarogryllus bordigalensis (Latreille, 1804); females here are only tentatively allocated to the taxon. Coloration varied much between the specimens, from light- to dark brown. There has been much confusion on the corresponding systematics and nomeclature: Tartarogryllus bordigalen sis (Latreille, 1804) was later referred to under Modicogryllus (comb. nov.) in Gorochov (1978) and subsequently Modicogryllus (Eumodicogryllus subg. n) in Gorochov (1986). EumodicogryIlus has then been raised to generic level, apparently becoming Eumodicogryllus bordigalensis (Latreille, 1804) in more recent publications (Gorochov, 1993; Gorochov \& Llorente, 2001).

It is of interest to note that apparently because of confusion with these nomenclature changes, all published records from the southeastern Aegean have for the moment been identified as Tartarogryllus bor digalensis or burdigalensis (Latreille, 1804) (Willemse, 1984; Baccetti, 1992; Önder et al. 1999a): it remains unknown whether these records from Greece and Turkey including the ones reported in this study all share the same specific status.

$$
\text { Gryllotalpidae - Grylotalpinae }
$$

\section{Gryllotalpa sp.}

Lipsos, 26 May-28 June 1997 (wetland pitfall traps), 30 $\sigma^{7}$, 2 우 우, 2 nymphs.

REMARKS: Krimbas (1960) has shown that there are two chromosomic races in Greece, with 14 and 19 chromosomes respectively. Solely based on karyotypic terms, Baccetti (1992) has described and named the 19-chromosome one; in his study, the holotype comes from the nearby island of Kos. Unlike other areas in eastern Mediterranean where (in addition to the karyotype) morphological features have been successfully used for taxonomic differentiation (Broza et al., 1998), the Greek taxa are currently distinguished only according to the chromosome number which can be measured in fresh specimens. Both races have been reported from the southeastern Aegean (Krimbas, 1960), so the specimens from Lipsos might belong to either of them or even both of them: it has been shown (Broza et al., 1998) that different Gryllotalpa species can be sympatric.

$$
\begin{gathered}
\text { Caelifera - Acridoidea } \\
\text { Pyrgomorphidae - Pyrgomorphinae }
\end{gathered}
$$

Pyrgomorpha conica conica (Olivier, 1791)

Lipsos, 19 May 1997, 1 \% . At phrygana.

REMARKS: This taxon is common throughout the Mediterranean region. Jannone (1936) gave information on a male specimen from the island of Kalimnos («Isola di Càlino») which, he speculated, could represent a different species. To the knowledge of the author, the scarcity of male Pyrgomorpha specimens from the Dodecanese area in any subsequent collection including this study, has prevented any further progress regarding his hypothesis.

$$
\text { Catantopidae - Calliptaminae }
$$

Calliptamus barbarus barbarus (Costa, 1836)

Marathi, 25 June 1997, 3 ㅇ

Arkioi, 23 June 1997, $2 \sigma^{\top} \sigma^{\pi}-1$ \& / 28 June 1997, 1 ㅇ. .

Sarakina, 27 June 1997, $10^{7}$

Lipsos, 26 May 1997, $1 \sigma^{7}$. At phrygana.

Faradonisia, 27 June 1997, $1 \sigma^{7}$.

Fragos, 11 July 1997, $20^{7} \sigma^{7}-3$ 우 우 .

Meg. Anthropofas, 20 June 1997, $1 \sigma^{\pi}-1$ ㅇ / 12 July 1997, $1 \sigma^{\pi}$ - 3 우 ㅇ․

Glaros, 10 July 1997, $20^{\top} \sigma^{\pi}-3$ 우 우.

REMARKS: The species is widely distributed around the Mediterranean and westwards, reaching 
China. Already discussed in Jago (1963) for several Palearctic populations, Hugueny \& Louveaux (1986) have statistically shown that variation in certain morphological characteristics of specimens from the western part of C.barbarus range (France and Morocco) correlates well with changing geographical latitude: they consider this a result of adaptive differentiation with regards to aridity and length of the growing season. Consequentlly and since colour was poorly preserved in material collected in this study, only the morphology of the phallic complex was used for classification (Jago, 1963): therefore, females are only tentatively referred to here.

Despite reports of extensive presence of the Calliptamus taxon in the area (Willemse, 1984), only $C$. barbarus was widely encountered, even in small and isolated islets. This may be contradictory to laboratory evidence which indicated that, compared to C. italicus (Linnaeus, 1758) C. barbarus is a bad flier (Louveaux, 1991). The possibility, however, that some of the females in the collection are indeed representatives of other Calliptamus species can not be excluded.

\section{Catantopidae - Cyrtacanthacridinae}

\section{Anacridiun aegyptium (Linnaeus, 1764)}

Lipsos, Hora, 25 May 1997, $10^{7}$.

REMARKS: Widely found along southern Europe, northern Africa and Asia, this species is also recorded from all over Greece.

\section{Acrididae - Oedipodinae}

Oedaleus decorus decorus (Germar, 1817)

Komoros, 18 June 1997, 1 immature ơ, 2 우 우.

Lira, 21 May 1997, 1 immature ơ / 21 May-24 June 1997 (pitfall traps), $1 \sigma^{\top} / 13$ June 1997, 2 우 오.

Lipsos, 1-2 June - 8 July 1997 (phrygana pitfall traps), $10^{7} /$ 13-14 July 1997, $10^{7}$.

Anidros, 24 June 1997, $1 \sigma^{7}$

Arkioi, 23 June 1997, $10^{\pi}, 2$ 우 우.

REMARKs: The species' range covers the Mediterranean and westwards; it is common throughout Greece.

\section{Acrotylus insubricus (Scopoli, 1786)}

Lipsos, 26 May-28 June 1997 (phrygana pitfall traps), $1 \sigma^{\top} .11$ July $1997,10^{7}$

REMARKS: The genus is widespread in the Mediterranean (Baccetti \& Capra, 1988).

\section{Sphingonotus sp.}

Lipsos, 19 May 1997, 1 ơ. At phrygana.

REMARKS: The systematics of this taxon in Greece remains to be understood.

Aiolopus strepens (Latreille, 1804)

Lipsos , 26 May-28 June 1997 (wetland pitfall traps), $1 \sigma^{\top}$. Leros, Gouves, 20 May 1997, $10^{7}$.

REMARKS: see under A. thalassinus.

Aiolopus thalassinus thalassinus (Fabricius, 1781)

Fragos / 18 May 1997, 1 ㅇ. .

Lipsos, 11 July 1997, $1 \sigma^{\top}, 1$ ㅇ At phrygana.

Komoros / 18 June 1997, $10^{7}$.

REMARKS: Distinction between A. thalassinus and A. strepens often proves difficult: Hollis (1968) distinguishes between them according to the form of the pronotum and the ratio of femur length/width, this being smaller than 3,64 for Aiolopus strepens and larger than 3,8 for Aiolopus thalassinus thalassinus. The specimens presented here were mostly identified according to the form of the pronotum and, whenever possible, the femur biometrics: the Komoros specimen was the only one presenting an intermediate value regarding the ratio of femur length/width $(3,74)$.

Both species are widespread in Greece and the Palearctic.

Duroniella fracta (Kraus, 1890) or Duroniella laticor nis (Kraus, 1909)

Leros, Gouves, 20 May 1997, 3 우 우 / 20 May-21 June 1997 (pitfall traps), 1 우 / 21 June 1997, $2 \sigma^{\top} \sigma^{7}$. Pitfall traps had been placed within the Gouves saltmarsh.

REMARKS: There are extremely few published reports of this taxon from Greece: Szijj (1992) apparently gives the first published evidence that Duroniella laticornis exists between the river Acheloos delta in central-west Greece and Nestos delta in eastern Makedhonia, Greece. He also characterises the taxon as an «extreme specialist» («extremer Spezialist») regarding habitat preferences. Naskrecki \& Ünal (1995) also mention Duroniella fracta from Greece. It is unknown whether these two (2) taxa are actually synonymous or indeed comprise separate species. Önder $e t$ al. (1999b) report on Duroniella laticornis from the neighboring Izmir (Bornova) in western coastal Turkey.

The findings in Leros indicate that the presence of the taxon is much more widespread than previously expected and corroborate the argument that the taxon shows strong habitat preferences, at least 
in Greece. Incidentally, the saltmarsh of Leros where Duroniella was solely recorded during the present study appears to resemble much the kind of habitat reported in Szijj (1992): vegetation mainly comprising Juncus species which were growing behind primary sand dunes.

\section{Acrididae - Gomphocerinae}

Dociostaurus maroccanus (Thunberg, 1815)

Marathi / 25 May 1997, $1 \sigma^{x}-3$ immature $\sigma^{7} \sigma^{7} / 25$ June 1997, $30^{7} 0^{7}-2$ 웅ㅇ.

Lipsos, 26 May 1997, 1 ơ / 11 July 1997, 1 우.

REMARKS: Coloration has been inadequately preserved in these specimens, therefore males were identified according to the length of the tegmina, the morphology of the epiphallus and the shape and size of the cingular valves as proposed in Soltani (1978); females are tentatively classified as belonging to the species.

Within the study area, specimens of this locust were only collected from abandoned cultivations on the islands of Marathi and Lipsos. Indeed, despite the occasional intensive outbreaks of the species within the Palearctic and its extended range from the Canary islands to Central Asia, Latchininsky (1998) has argued that the ecological requirements of the species are «rather narrow»: the habitat the insect usually associates with comprises a mosaic of patches of bare soil and dry-steppe vegetation of tufty, short grasses, sedges and ephemeral spring forbs including Poa bulbosa. Apparently this habitat can result from low spring rainfall (optim. 100 $\mathrm{mm}$ approx.), deforestation, shrub destruction and/or abandonment of agriculture.

\section{Discussion}

Evidently, a few Orthopteran taxa (Duroniella, Melanogryllus desertus, Eumodicogryllus) previously reported from larger insular and continental land regions in the Aegean Sea can indeed occur in small isolated spots within the archipelago. It is not known whether the paleogeographical pattern of island isolation history or any contemporary ecological processes, for example successful immigration, better explain current Orthoptera ranges in the Aegean (for other taxa see Trihas, 1996; Dennis et al., 2000). In geological terms, most of the northern Dodecanese islands are assumed to have been linked to the mainland (now the western Turkish coast) until recently, that is at least during the last well known cold age about 18.000 y BP. This explains the low number of island endemics currently recorded from the southeastern Aegean (Willemse, 1984 and studies therein) as in other regions, strong evidence of autochthonous evolution in Orthoptera (Gryllidae) was related to geographical separation for at least 185000 years (Weissman \& Rentz, 1976). On the other hand, strong ecological affinities have been difficult to show in Orthoptera unless the study operates at a small-scale level (as in Kindvall \& Ahlén, 1992) and accidental records and random findings can be objectively assessed (Alexander, 1964). Yet, the coincidental but operationally unbiased use of the pitfall traps during this study provides evidence that species of large range and therefore of assumingly opportunistic character may be confined to certain habitats: despite the wide use of pitfall traps in nine (9) different areas, Duroniella, all three of the Gryllidae species and the single Gryllotalpidae taxon were reported solely from the two (2) wetland sites, indeed tiny ones. It is speculated that the summer dryness of the Aegean islands may favor this situation as, contrary to the Acrididae which are generally known to be highly adapted for xeric environments (Bernays, 1990), Gryllidae nay be less prone to losing water.

\section{ACKNOWLEDGEMENTS}

This data would not have reached the present stage without the cordial help of Dr. F. Willemse (Eygeshoven, Netherlands) who has constantly assisted the author through many perplexing questions posed by this study, including species identification. Prof. A. Legakis made possible participation in the project and access to all the facilities of the Laboratory of Invertebrate Ecology, Systematics and Biogeography (Department of Biology, University of Athens, Greece). Dr. P. Petrakis (National Forest Research Institute, Athens) has kindly provided many important suggestions to the author and has reviewed an earlier draft version. M-A. Dunais and N. Zafiris have created the map. Dr. Kjell Arne Johanson has cordially allowed free access to the excellent library resources of the Department of Entomology in the Swedish Museum of Natural History (Stockholm). Ms M.Dimaki has enabled the use of the microscope facilities of the Goulandris Museum of Natural History (Greece). Several friends and colleagues from around the world provided papers and other literature information.

Specimens presented here will be shared between the Zoological Museum-University of Athens, the University of Crete Museum of Natural History (Crete, Greece) and the collection of the author. This project was partially supported by the European Communities DG-Environment LIFE financial tool (code number LIFE96 NAT / GR / 3221). 


\section{References}

AlexANDER, G., 1964. Occurrence of grasshoppers as accidentals in the Rocky Mountains of northern Colorado. Ecology, 45: 77-86

Ausden, M., 1996. Invertebrates. In: Sutherland, W.J. (ed.), Ecological Census Techniques. A handbook, Cambridge University Press. Cambridge: 139-177.

BACCETTI, B., 1992. Notulae Orthopterologicae. 50. Su alcuni Ortotteroidei del Mediterraneo Orientale, Fragmenta Entomologica, 23(2): 247-276.

BACCETTI, B. \& CAPRA, F., 1988. Notulae Orthopterologicae. 46. Revisione delle species Mediterranee del gen. Acrotylus Fieb. Redia, 71: 565-588

BERNAYS, E. A., 1990. Water regulation. In: Chapman R. F. \& Joern, A. (eds.). Biology of grasshoppers. John Wiley \& Sons. New York: 129-141.

Broza, M., Blondheim, S. \& Nevo, E., 1998. New species of mole crickets of the Gryllotalpa gryllotalpa group (Orthoptera: Gryllotalpidae) from Israel, based on morphology, song recordings, chromosomes and cuticular hydrocarbons, with comments on the distribution of the group in Europe and the Mediterranean region. Systematic Entomology, 23: 125-135.

ChOPARD, L., 1962. Les divisions du genre Gryllus basées sur l'étude de l'appareil copulateur (Orth. Gryllidae) Eos (Madrid), [1961], 37: 267-288.

Delipetrou, P. \& ECONOMIDOU, E., 2001. NATURAsite GR-4120004 In: Ekby (coord): [Identification and description of habitat types in areas of special inte rest regarding nature conservation.] EPPER/subproject 3/metro 3.3. Ministry of Environment, Planning and Public Works. unpublished report (in Greek).

Dennis, R. L. H., Shreeve, T. G., Olivier, A. \& Coutsis, J. G., 2000. Contemporary geography dominates butterfly diversity gradient within the Aegean archipelago (Lepidoptera: Papilionoidea, Hesperioidea). Journal of Biogeography, 27: 1365-1383.

Dermitzakis, M. D. \& SondaAr, P. Y., 1978. The importance of fossil mammals in reconstructing paleogeography with special reference to the Pleistocene Aegean archipelago Annales Géologiques des pays Helléniques, 1e série, 31(12): 808-840.

Dimopoulos, P. \& Zervou, S., 2001. NATURAsite GR4220012. In: Ekby (coord): [Identification and des cription of habitat types in areas of special interest regarding nature conservation.] EPPER/subproject 3/metro 3.3. Ministry of Environment, Planning and Public Works. Unpublished report (in Greek).

ECONOMIDOU, E., 1995. Vegetation and Flora. In: Papakonstantinou, K. et al.: [Ecological survey in the northern Dodecanese archipelago - report of an expe dition of the Hellenic Ornithological Society across the islands and islets of the northern part of the Prefecture of Dodecanisa, Part A.] Hellenic Ornithological Society. Athens. Unpublished report (in Greek).
Economidou, E., Sklavounos G., Kapourani, E., Portolou, D., Papakonstantinou, K., Bousbouras, D., Papapavlou, K., Kotzambopoulos A., Nikolaidis, V., Mom, Gazelia, A. \& Gerogouli, E., 1999. [Special Environmental Study of the Arkioi, Lipsi and Agathonisi islands and islets-Natura site 2000 GR4210010.] Part A'-Ministry of Environment, Planning and Public Works (in Greek).

Gorochov, A. V., 1978. [Crickets of the genera Tartarogryllus Tarb. and Modicogryllus Chop. (Orthoptera, Gryllidae) in Middle Asia.] Entomologicheskoe Obozrenie, 57: 97-105 (in Russian).

Gorochov, A. V., 1986. [New and little known crickets (Orthoptera, Grylloidea) from the Middle Asia and adjacent territories.] Proceedings of the Zoological Institute, Leningrad, 140: 3-15 (in Russian).

Gorochov, A. V., 1993. Grylloidea (Orthoptera) of Saudi Arabia and adjacent countries Fauna of Saudi Arabia, 13: 79-97.

Gorochov, A. V. \& Llorente, V., 2001. Estudio taxonómico preliminar de los Grylloidea de España (Insecta, Orthoptera). Graellsia, 57(2): 95-139.

Heller, K-G. \& ReINHOLD, K., 1992. A new bushcricket of the genus Poecilimon from the Greek islands (Orthoptera: Phaneropterinae). Tijdschrift voor Entomologie, 135: 163-168.

Hollis, D., 1968. A revision of the genus Aiolopus Fieber (Orthoptera: Acridoidea) Bulletin of the British Museum of Natural History (Entomology), 22: 309-355.

Hugueny, B. \& Louveaux, A., 1986. Gradient d'aridité et variation latitudinale de la taille, dans des populations de Calliptamus barbarus (Costa, 1836) (Insecte, Orthoptère, Acrididae). Acta Oecologica, 7(4): 317-333.

JAGO, N. D., 1963. A revision of the genus Calliptamus Serville (Orthoptera: Acrididae) Bulletin of the British Museum of Natural History (Entomology), 13(9): 287-350.

JANNONE, G., 1940. Nuovi contributi alla conoscenza della fauna delle isole Italiane dell'Egeo - XIV. Ulteriori notizie bio-ecologiche e sistematiche sull'Ortotterofauna in relazione a materiale raccolto in Rodi e Stampalia nel 1938. Bollettino del Reale Laboratorio di Entomologia Agraria di Portici, 3: 325-343.

JANNONE, G., 1936. Nuovi contributi alla conoscenza della fauna delle isole Italiane dell'Egeo - V. Studio bio-ecologico e sistematico dell'Ortotterofauna con notizie sui Blattoidei, Mantoidei e Fasmoidei. Bollettino del Reale Laboratorio di Entomologia Agraria di Portici, 29: 47-248.

KARABAG, T., 1951. Revision of the genus Bucephaloptera Ebner (Orthoptera, Tettigoniidae). Eos Madrid, tomo extraordinario, 1950: 275-282.

Kindvall, O. \& AhlÉN, I., 1992. Geometrical factors and metapopulation dynamics of the bush cricket 
Metrioptera bicolor Philippi (Orthoptera: Tettigoniidae). Conservation Biology, 6: 520-529.

KrimbAS, K., 1960. Ta didyma eide Gryllotalpa en Elladi, Kitarologiki ke morfologiki erevna. Report to the Ministry of Agriculture. 27 pp.

LA GRECA, M., 1999. Il contributo degli Ortotteri (Insecta) alla conoscenza della biogeografia dell'Anatolia: la componente godwaniana. Biogeographia, 20: 179-200.

LATCHININSKY, A. V., 1998. Moroccan locust Dociostaurus maroccanus (Thunberg, 1815): a faunistic rarity or an important economic pest? Journal of Insect Conservation, 2: 167-178.

Llorente Del Moral, V., 1980. Los Ortopteroides del Coto Doñana (Huelva). Eos (Madrid), [1978], 54: 117-165.

Louveaux, A., 1991. Instabilité démographique et stratégie de dispersion des Acridiens: un exemple chez deus orthopteres Calliptaminae. Bulletin de la Société Zoologique de France, 116(3-4): 243-251.

NASKRECKI, P. \& ÜNAL, M., 1995. The Orthoptera of Hatay Province, S. Turkey. Beiträge zur Entomologie, 45(2): 393-419.

Önder, F., Pehlivan, E., Karsavuran, Y., Tezcan, S. \& KismaLi, S., 1999a. Catalogue of the collection of Gryllidae and Gryllotalpidae (Orthoptera) preserved in the prof. Dr. Niyazi Lodos Museum, Izmir, Turkey. Türkiye Entomoloji Dergisi, 23(2): 83-90.

Önder, F., Pehlivan, E., Karsavuran, Y., Tezcan, S. \& Kismali, S., 1999b. Catalogue of the collection of Pamphagidae, Pyrgomorphidae, Catantopidae and Acrididae (Orthoptera: Acridoidea) preserved in the prof. Dr. Niyazi Lodos Museum, Izmir, Turkey. Türkiye Entomoloji Dergisi, 23(3): 163-178.

Önder, F., Pehlivan, E., Karsavuran, Y., Tezcan, S. \& KismaLI, S., 1999c. Catalogue of the collection of Tettigoniidae (Orthoptera) preserved in the prof. Dr. Niyazi Lodos Museum, Izmir, Turkey. Türkiye Entomoloji Dergisi, 23(4): 243-250.

PANITSA, M. \& TZANOUdAKIS, D., 2001. NATURA site GR-4210010 In: Ekby (coord): [Identification and description of habitat types in areas of special inte rest regarding nature conservation.] EPPER/subproject 3/metro 3.3. Ministry of Environment, Planning and Public Works. Unpublished report (in Greek).

RoMÃo, C., (compiler). 1996. Interpretation manual of European Union habitats, DG XI - Environment, Nuclear Safety and Civil protection, version EU 15. $145 \mathrm{pp}$.
Salman, S., 1983. Turkish bush crickets of the genus Eupholidoptera (Decticinae). Systematic Entomology, 8(3): 313-338

SzIJJ, J., 1992. Ökologie der Heuschrecken in den Flussmündungen Griechenlands im Zusammenhang mit der landschaftsökologischen Entwicklung (Orthoptera, Saltatoria). Deutsche Entomologische Zeitschrift, 39(1-3): 1-53.

Soltani, A. A., 1978. Preliminary synonymy and description of new species in the genus Dociostaurus Fieber, 1853 (Orthoptera: Acridoidea; Acrididae, Gomphocerinae) with a key to the species in the genus. Journal of Entomological Society of Iran, suppl. 2: 1-93.

TRIHAS, A., 1996. [Ecology and biogeography of the soil beetles in the southern Aegean.] $\mathrm{PhD}$ Thesis. University of Crete (in Greek).

ÜNAL, M., 2000. Notes on Orthoptera of Western Turkey, with description of a new genus and four new species. Journal of Orthoptera Research, 8: 243-255.

Weissman, D. B., \& Rentz D. C., 1976. Zoogeography of the grasshoppers and their relatives (Orthoptera) on the California Channel islands. Journal of Biogeography, 3: 105-114.

Willemse, F., 1980. Classification and distribution of the species of Eupholidoptera Ramme of Greece (Orthoptera, Tettigoniodea, Decticinae). Tijdschrift voor Entomologie, 123: 39-69.

Willemse, F., 1982. A survey of the Greek species of Poecilimon Fieber, 1853 (Orthoptera, Ensifera), Phaneropterinae). Tijdschrift voor Entomologie, 125: 155-203.

Willemse, F., 1984. Catalogue of the Orthoptera of Greece. Fauna Graeciae, 1: 1-275.

WiLlemse, F., 1985. A key to the Orthoptera species of Greece. Fauna Graeciae, 2: 1-288.

Willemse, F. \& Heller, K-G., 1992. Notes on systematics of Greek species of Poecilimon Fischer, 1853 (Orthoptera: Phaneropterinae). Tijdschrift voor Entomologie, 135: 299-315.
Recibido, 29-III-2004

Aceptado, 13-IV-2005

Publicado, 14-VII-2005 


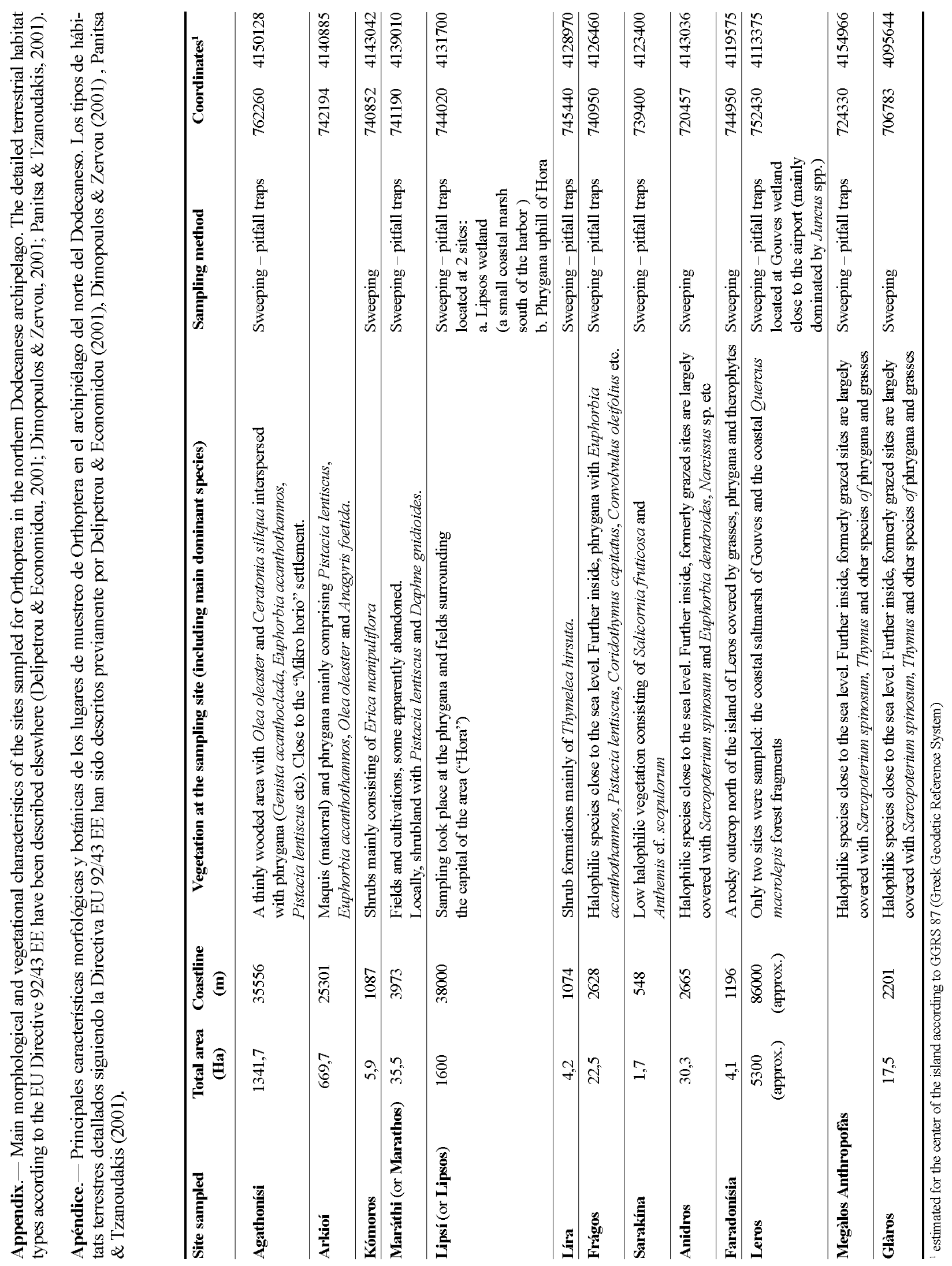

